R. Rohatynskyi, Dr. Sc. (Tech.), Prof., orcid.org/0000-0001-8536-4599, N. Harmatiy, Cand. Sc. (Econ.), orcid.org/0000-0003-4426-9223, I. Fedyshyn, Cand. Sc. (Econ.), orcid.org/0000-0001-5531-4566, D. Dmytriv, Cand. Sc. (Tech.), orcid.org/0000-0003-3164-5832
Ternopil Ivan Puluj National Technical University, Ternopil, Ukraine, e-mail: rogatynskyi@gmail.com; ira.fedyshyn@ gmail.com

\title{
MODELING THE DEVELOPMENT OF MACHINE-BUILDING INDUSTRY ON THE BASIS OF THE FUZZY SETS THEORY
}

Purpose. To analyze the state of development of Ukraine's machine-building industry as a whole and its individual sub-sectors at the background of modern macro, micro-environment and in the context of new geopolitical situation. The task was set to model the development of the industry on the basis of the theory of fuzzy sets and to formulate suggestions for economic cooperation with foreign investors, in particular EU countries in the field of machine-building.

Methodology. The study is based on general scientific methods (analysis, synthesis, comparison, formalization, and others) and methods of statistical data analysis. The data regarding the main indicators of engineering enterprises' activities (the number of enterprises, the number of employed workers, average monthly nominal salary of workers, the volume of products sold by machine-building enterprises), as well as the volume of direct investments from Ukraine to economies of the world for the period of 2010-2017, was provided by the State Statistics Service of Ukraine. The apparatus of fuzzy logic (fuzzy sets) was used for studying and modeling the development of Ukraine's machine-building industry in the near future. This is one of the most effective mathematical theories aimed at formalizing and processing uncertainty of information.

Findings. The paper discusses the development trends of the machine-building in Ukraine for the period of 2010-2017. Despite the fact that in the structure of investments in fixed assets the machine-building complex makes up a large third, it was found that during 2010-2017 the number of enterprises and employed workers involved in the field of machine-building was steadily declining. Using the tools of economic and mathematical modeling based on fuzzy sets, the authors developed a model for assessing the level of development of the machine-building industry in the near future. According to the simulation performed, an optimistic and pessimistic forecast was developed taking into account and without taking into account the proposed parameters that currently affect the activities of machine-building enterprises in the context of the new geopolitical situation.

Originality. Using the tools of economic and mathematical modeling on the basis of fuzzy sets, a model for assessing the level of development of the machine-building industry for the near future was elaborated. Scientific originality is in the selection of quantitative and qualitative factors that have a significant impact on the dynamics of the development of machine-building in Ukraine. The improvement of the suggested parameters will bring Ukraine's machine-building to the European and world markets and will significantly improve the macroeconomic indicators of the national economy.

Practical value. The model of assessing the state of Ukraine's machine-building industry developed by the authors will allow determining this state taking into account qualitative and quantitative factors, adapting these parameters to the real conditions of Ukraine's economy development and diversify the production volume of machine-building enterprises in the near future.

Keywords: economic development, engineering enterprises, metallurgy, automotive industry, the fuzzy sets theory

Introduction. The processes of globalization have recently been gaining high impact and are of an all-embracing nature. Today it is important for Ukraine to become an equal partner of the world community, but not a raw material appendage of highly developed countries. In the modern Ukrainian economy, industrial enterprises, based on their role in creating the gross domestic product (GDP), occupy a special place in the system of organization of national production. Machinebuilding is an important branch of industry. The level of development of machine-building is one of the main indicators of economic and, above all, industrial development of the country [1]. Machine-building plays a key role in ensuring the development of the state's economy and is the basis for other industries, contributing to or reducing their competitiveness both inside and beyond the country. China, Germany, the USA, Japan, Hong Kong, Korea, Mexico, France, Singapore, Italy, Great Britain, Taiwan are among the leaders in the machine-building sector in the world. These countries are able to independently produce almost all types of machinery, equipment and hardware. Individual countries of Eastern and Western Europe, Brazil, India, Singapore produce only certain types of machine-building products, albeit at a rather high level [2]. For example, according to the overall foreign trade index, Germany ranks second, in terms of commodity exports - the second, in terms of investment exports - the

(C) Rohatynskyi R., Harmatiy N., Fedyshyn I., Dmytriv D., 2020 world's third largest. More than $60 \%$ of commodity exports is accounted for machine-building products, followed by products of the chemical industry and some types of food products. In comparison with 1995, in 2015 the change of the countryleader in the machine-building market took place. It became China with a market share equal to $17.0 \%$ [3].

Ukraine was also in this group before the beginning of the 1990 s, the machine-building sector of which was the leading branch of economy. However, today the reduction of performance of domestic machine-building goes in parallel with its scientific and technical demission [2].

Literature review. Successful functioning of machinebuilding enterprises is a key component of the development of economies in the world, which is affected by many factors from skilled labor to the problem of environmental protection. Therefore, this issue is being studied by many foreign and domestic economists.

Thus, in particular, Jean Tirole, the Nobel Prize winner, reveals the essence of relationship between economics and politics affecting macroeconomic challenges, analyzes the impact of the digital revolution, innovation and the correct balance between the market and regulation. According to the economist, country-wide economic decisions cannot be understood without the context of fields such as politics. He states that "economic agents react to incentives, some of which derive from the social groups to which they belong..." [4]. Tirole applies his macroeconomic insight to microeconomic 
questions like digital platforms and their influence on employment, intellectual property, competition laws and policy and finally, the regulation of network industries. Tirole correctly underlines the importance of new technology explaining that digitalization has an impact on intellectual property rights, competition law, labor law, taxation and regulation in general. The digital economy is bringing extraordinary technological progress that is giving us better health, as well as more time and purchasing power, but it also creates dangers we cannot ignore [4]. His scientific reflections are particularly relevant today, at the time of intensified competition and the instability of political and economic systems.

Since the main factor influencing successful activity of industrial enterprises is the innovative component of their production, in this context of scientific interest is the work by I. V. Bagrov and T. I. Tyshchenko [5], where they analyze components that form the properties of innovative potential of an industrial enterprise and provide a methodology for their calculation, which makes it possible to visually and more carefully compare the potentials of different industrial enterprises, to use formal and heuristic methods of evaluation.

The research [6] reveals peculiarities of innovative development of industrial enterprises in 10 regions of Ukraine, and reveals a close correlation between the number of innovative enterprises and the number of enterprises that spend money on domestic research, purchase of machinery, equipment and software. Problems are detected and directions of their solution are determined. This work is of considerable interest from a point of estimated relationship between the number of industrial enterprises and their innovative activity, as well as the formulation of tasks that are appropriate to solve to increase the innovation activity of machine-building complex. However, no proposals were made regarding further industrial development that would take into account quantitative and qualitative parameters of its functioning.

In the paper [7] Hakhovych N.G., Zavhorodnia M.Yu. analyze the dynamics of added value in production of machine-building products in world countries and provide a detailed substantiated retrospective analysis of the development of Ukrainian machine-building industry in particular. The paper offers solutions for the development of main industries. But issues remained unsolved related to ensuring competitiveness of Ukraine's machine-building in an unstable environment, and the authors do not take into account the factors of influence.

Herasymchuk V. G. [8], Korotkyi Y.V [9] analyze trends of development of machine-building enterprises of Ukraine, conditions of their functioning and development prospects. These works are of interest as they actualize analytical data of the development of machine-building complex. Information that is considered in the works by these scientists can serve as the basis for further modeling the development of machinebuilding in the regions of Ukraine and economy as a whole.

Unsolved aspects of the problem. In today's high dynamics of external environment, Ukrainian industrial enterprises, in particular in the field of machine-building, significantly feel the pressure of such factors as rising costs, increasing competition, increasing requirements for quality and nomenclature. This, in turn, promotes increased demands concerning production flexibility and real-time management. Not all enterprises implement a complex strategy for innovation.

Modern scientific literature does not pay enough attention to methods of predictive analytics that can be implemented in many business processes - from the planning stage to the production stage. It is also worth noting that very often quantitative methods are used to construct mathematical models that do not allow operating with uncertainty.

Despite the growing interest in the method for modeling the development of certain economic systems based on fuzzy set theory, the analysis of recent studies and publications points to their insufficient implementation.
Thus, the absence of domestic and foreign research studies and publications using modern methods of economic and mathematical modeling, including fuzzy sets theory, and the absence of an optimistic and pessimistic forecast for the development of Ukraine's machine-building, availability of data for analysis, which allows identifying and evaluating the influence of factors on activities of machine-building enterprises, the appearance of new economic models and approaches that affect both production and business environment made it necessary to conduct this research.

Purpose. The purpose of this research is to analyze development of Ukrainian machine-building industry as a whole and its individual sub-sectors against the backdrop of the modern macro- and micro-environment and in the context of the new geopolitical situation. In order to develop suggestions for economic cooperation with foreign investors, including EU countries, the field of machine-building, the goal was set to model further development of the industry based on the fuzzy set theory.

Methods. Indicators of Ukraine's machine-building enterprises' activity are provided by the State Statistics Service of Ukraine and analytical reports. All data cover the period of 2010-2017. The use of the tools of economic and mathematical modeling allowed simulating optimistic and pessimistic results of the development of Ukraine's machine-building industry and investigating the possibility of influence and shift of the dynamics of specific indicators.

Very often quantitative methods are used for the construction of mathematical models. But they do not allow operating with uncertainty. However, the efficiency of uncertainty verification of information directly depends on the choice of mathematical basis justified by mathematical theory. It is worth noting that nowadays there are a number of theories intended to formalize uncertain information: probability theory, subjective probability theory, the theory of interval average, multivalued logic, fuzzy set theory (fuzzy logic).

The basic ideas of the fuzzy set theory were worked out by mathematician L. Zade, that have recently been one of the most common areas of research in the field of management of economic systems. The theory of fuzzy sets allows effective modeling of nonlinear functions of any complexity. The mathematical apparatus allows specifying indicators and parameters of the model in the form of linguistic variables, the principal difference of which from the numerical variables is in the fact that their values are not numbers, but words or sentences in the natural language [10]. This mathematical theory from unified positions allows considering various types of uncertainties using the possibilities of other theories and obtaining a qualitatively new, better result. Taking into account that the development of machine-building is influenced not only by quantitative parameters but also by qualitative ones (unfavorable political situation in the eastern part of the country, changes in the external strategy of the national economy development, low solvency of the population of Ukraine, high level of corruption, and others), in our opinion, it is the toolkit on the base of fuzzy sets which allows formalizing the task of machine-building development.

The main advantages from the use of the analytical apparatus of the theory of fuzzy logic are [11]:

- ability to use data given unclearly (statistical surveys, and so on);

- fuzzy formalization of evaluation and comparison criteria (using the criteria "majority", "possible", "predominantly", and others);

- conducting a qualitative assessment of both input data and outcomes;

- rapid modeling of complex dynamical systems and their comparative analysis with a given degree of accuracy.

Mathematical modeling using the principles of fuzzy logic requires the choice of a method of constructing membership functions that will ensure the formalization of fuzzy terms. 
The fuzzy set theory gives the opportunity to use different methods of constructing membership functions. Therefore, it is advisable to choose a number of criteria that would help to solve the issue of building membership functions. The specific type of membership functions is determined on the basis of various additional assumptions about the properties of these functions (symmetry, monotony, continuity of the first derivative, and so on), taking into account the specificity of the existing uncertainty and the real situation. In particular, we propose fuzzy numbers of input and output parameters with a triangular representation of the membership function $\mu(\mathrm{t})$.

They are labeled $\bar{t}=\left(t_{\min }, t_{c}, t_{\max }\right)$, where $t_{\min }, t_{\max }, t_{c}$ are respectively, the minimum, maximum value and some assessment of the central value (mathematical expectation, modes, medians, etc.) of a particular parameter and have a membership function 1 .

$$
\mu(t)=\left\{\begin{array}{l}
\frac{t-t_{\min }}{t_{c}-t_{\min }}, \text { for } \quad t_{\min } \leq t \leq t_{c} \\
\frac{t-t_{\max }}{t_{c}-t_{\max }}, \text { for } \quad t_{c} \leq t \leq t_{\max }
\end{array} .\right.
$$

For modeling complex dynamic systems MatLab and Statistica software were used, which have modules that allowed processing data on fuzzy sets.

Results. The machine-building complex of Ukraine includes more than 20 branches, 58 sub-sectors, including 11.267 enterprises (146 large, 1834 medium-sized, 9287 small ones), employing about 1.5 million employees [12]. Machinebuilding is also of the growing significance for Ukrainian economy because of the fact that it includes a significant share of the fixed and operating assets value and employs almost $1 / 5$ of the number of employees in [13]. The machine-building complex ranks second after metallurgy concerning the value of major industrial and production assets of large and medium-sized industrial enterprises; in the structure of fixed capital investment, machine-building complex accounts for a third part and it ranks third in contributions to the state budget [14].

Ukraine has all the preconditions for machine-building development since there is raw material base, workforce and good geographical location. But despite this, the volumes of machine-building production in 2014 decreased by almost three times in comparison with 2004. Domestic products, with the exception of their separate types, are not competitive both in the world market and in the domestic markets [9]. Despite the significant contribution of machine-building to the development of the national economy, it should be noted that its share in the structure of industry in Ukraine during $2013-$ $2015(2013-8.6 \%, 2014-7.2 \%, 2015-6.5 \%)$ [12].

At the same time, the conflict with the Russian Federation and breakdown of technological chains with the enterprises of the Crimea and Donbas negatively affected the production of machine-building products. This was evidenced by the continuation of the decline in machinery production in 2015 by $19.3 \%$ and the decrease in trade turnover in the industry. In 2016 , with a general $2.4 \%$ increase in the industrial production, machine-building grew by $1.3 \%$. This is the result of the revival of some segments of the domestic market, including the production of defense commodities. Experts estimate the total amount of defense production at UAH 50 billion, and also in recent years, the largest business entity of the defense industrial complex - state group corporation "Ukroboronprom" has increased production several-fold, reaching \$ 600 million in 2015 [7].

The number of enterprises and the number of employed and hired workers in the field of machine-building for 2010-2017 are presented in Table 1.

During 2010-2017 the number of enterprises and employees in the field of machine-building was steadily declining. However, statistics showed steady growth of workers salary in the field of machine-building, as well as the increase in the volume of sales of machine-building enterprises in the hryvnia equivalent, but, taking into account inflationary processes, this tendency should be considered as regularity. For example, according to the State Statistics Service of Ukraine, the GDP deflator for the third quarter of 2015 was at $37.8 \%$, and inflation in Ukraine in 2015 increased to $43.3 \%$ (State Statistics Committee of Ukraine) and reached its maximum for the last 20 years [15]

Domestic engineering today is experiencing hard times. In the period of 2013-2014, the manufacture of machinery was reduced by 17 and $24 \%$ respectively. The largest decline was observed in the production of transport machine-building. The volume of locomotives production in 2014 decreased by $62 \%$ compared to 2013. The production of cars in 2014 compared to 2013 decreased by $35 \%$ [9].

According to the data of "Ukrautoprom" in August 2018 the volume of motor transport production in Ukraine decreased by $37 \%$ compared to the corresponding period of 2017. In August 2018, only 470 units of motor vehicles were produced by Ukrainian factories. The largest result was demonstrated by the "Eurocar" plant, which comprised 413 Skoda cars. At the same time, in relation to August 2017, the volume of large-wheel assembly at "Eurocar" decreased by $27 \%$. The production of trucks was limited to only one car, against 32 units a year earlier. Manufacturers of buses have been producing 56 cars monthly, which is $18 \%$ less than last year.

During January-September of the year 2018, 4544 units of motor vehicles were manufactured in Ukraine or $7 \%$ less than during the same period of the previous year [16]

During 2017, almost 1 million vehicles with a foreign registration were imported into Ukraine. Now more than 246.4 thousand cars with foreign registration stay in Ukraine illegally [17].

Table 1

Indicators of activity of machine-building enterprises in the period of 2010-2017 [16]

\begin{tabular}{|c|c|c|c|c|}
\hline Years & $\begin{array}{c}\text { The number of } \\
\text { enterprises, units }\end{array}$ & $\begin{array}{c}\text { The number of } \\
\text { employees, thousands }\end{array}$ & $\begin{array}{c}\text { Average monthly nominal } \\
\text { salary of employees, UAH }\end{array}$ & $\begin{array}{c}\text { Volume of sales by mechanical } \\
\text { engineering enterprises, million UAH }\end{array}$ \\
\hline 2010 & 4736 & 482.3 & 2243 & 99270.5 \\
\hline 2011 & 4791 & 499.4 & 2741 & 130847.9 \\
\hline 2012 & 4546 & 520.8 & 3042 & 140539.3 \\
\hline 2013 & 5103 & 488.8 & 3229 & 113926.6 \\
\hline 2014 & 4460 & 422.3 & 3336 & 101924.7 \\
\hline 2015 & 4483 & 370.4 & 4211 & 115261.7 \\
\hline 2016 & 4209 & 353.6 & 5344 & 131351.8 \\
\hline 2017 & 4481 & 358.8 & 7357 & 167649.3 \\
\hline
\end{tabular}


Against the background of negative trends in production of domestic automotive engineering, in 2016 AvtoKrAZ completed obtaining of the international certificate to enter new markets. This public joint-stock company produces 33 base models, more than 260 modifications and complete sets of automobile equipment by "KrAZ" for work in all branches of economy and the Armed Forces of Ukraine. The enterprise, which supplied $70 \%$ of the production to Russia, and received from there the same percentage of components, has completely switched to cooperation with enterprises of Ukraine and Europe. In the framework of import substitution the order from "AvtoKrAZ" received companies from Uzhhorod, Berdychev, Odesa, Lviv, Zhytomyr, and Belarus as well. The main component, the engines, today produce: Minsk Motor Plant, Deutz, Cummins, Daimler, Fiat, WEICHAI [7]. However, since August 2016, KrAZ has ceased to disclose information about its production volumes.

In conditions of import price increase for high-tech equipment and component parts and significant export-oriented policy, machine-building provides about $39.1 \%$ of the capacity of the domestic market. In the general structure of Ukraine's exports in 2016, the share of machine-building was $11.9 \%$, with an index of 4.34 billion dollars US, which was $9.2 \%$ less than the indicator in 2015. For example, in 2017 tractors were imported totaling to 2.5 billion dollars. And domestic tractorbuilding plants remain underutilized.

At the same time, the industry's dependence on the import of machine-building products is growing. This is primarily due to the low technological level of domestic production [7].

In conditions of liberalization and globalization of the economy, accompanied by large-scale transformations of the organizational and economic mechanism of management in Ukraine, machine-building was one of the sectors that were severely affected during the reform process. Although in some industries they managed to maintain production potential, but the severance of economic ties with other countries - the former Soviet republics, the lack of an effective state program for the development of machine-building, the weakness of regulatory norms in protecting domestic producers from unwarranted imports of machine-building products and so on, led to a significant loss of industrial and scientific potential of the industry. As a result, today in the general structure of domestic exports, machine-building reaches only $13-19 \%$, and the trade balance is negative in almost all commodity groups of the industry [3].

In general, it can be said that after 2008 (accession to the WTO), the trend of the negative balance increased (Kudriachenko, 2009). In recent years (2012-2017), the growth rate of imports from the EU member states was higher than the export rate, which resulted in the growth of the negative trade surplus. In 2012, the negative balance with the EU countries was about $\$ 9.1$ billion, in $2013-\$ 10.3$ billion, in $2014-$ $\$ 4.1$ billion. The negative balance of foreign trade of Ukraine in 2015 amounted to $\$ 2.3$ billion. In 2017, the goods were exported at the sum of 17 billion 533 million dollars, while imports amounted to 20 billion 799 million dollars in currency [15].

At this stage Ukrainian enterprises are forced to buy new equipment from the EU on prepayment terms. After creating a free trade area, equipment can be leased or loaned on very favorable terms.

It is quite obvious that for today the state support of the national producer is insufficient. The government is inclined to sign multi-million contracts with foreign suppliers, but lobbies the interests of the domestic machine-building complex on the world market insufficiently.

However, the research showed that such engineering corporations and enterprises as public joint-stock company "FED", Aton Group, UBC Group, Discovery Drilling Equipment focus on modern management methods and tech- nologies. Newly founded firms adapt to existing realities much faster - no matter what they are. In this context, new methods for financing and management of machine-building enterprises are most clearly demonstrated. Today the key role is given to engineering, company's CEO, emphasizing the key role of the workers and their high qualification [17].

In the context of the new geopolitical situation of the national economy, the innovative component in production is the main component for accelerating the development of the machine-building industry. Machine-building is a risky activity in unstable political and economic systems, influenced by many factors of fuzzy, so to speak, blurred nature.

In modeling the level of development of Ukraine's machine-building industry, taking into account quantitative and qualitative factors, five input parameters $\left(x_{1}, x_{2}, \ldots, x_{5}\right)$ and one output parameter $(Y)$ were identified. The description is given in Table 2.

Graphic presentation of the model is shown in Fig. 1.

The level of expenditures for research (by sectors) - indicator $x_{1}$ - according to the State Statistics Service of Ukraine [15] ranges from 19 to $21.3 \%$ (corresponds to a low level of influence - term " $L$ ") of total innovation costs in the industry, is insufficient and needs significant improvement. The share of innovatively active enterprises (by types of economic activity) in the total volume of innovatively active industrial enterprises - indicator $x_{2}$ - ranges from 18.9 to $22.6 \%$ (corresponds to a low level of influence - term " $L$ "). The share of machinery, equipment, vehicles and devices in the structure of Ukrainian commodity exports - indicator $x_{3}$ - ranges within $8.1-36.8 \%$ (corresponds to low and medium level of influence - terms "L" and "M").

According to [18], the share of transport engineering in the total export volume of machine-building is $12.0 \%$, the share of heavy machine-building is $19.9 \%$, and the share of

Table 2

Parameters of the model of the development level of machine-building industry of Ukraine

\begin{tabular}{|l|c|}
\hline \multicolumn{1}{|c|}{ Parameter name } & Marking \\
\hline $\begin{array}{l}\text { level of development of machine-building in the near } \\
\text { future }\end{array}$ & $Y$ \\
\hline $\begin{array}{l}\text { level of conducting scientific research in the field of } \\
\text { machine-building (research and development) [15] }\end{array}$ & $x_{1}$ \\
\hline the number of innovative industrial enterprises [15] & $x_{2}$ \\
\hline $\begin{array}{l}\text { share of machinery, equipment, vehicles and devices in } \\
\text { the structure of Ukrainian commodity exports [18] }\end{array}$ & $x_{3}$ \\
\hline level of export of machine-building products [18] & $x_{4}$ \\
\hline $\begin{array}{l}\text { updating the legislative and policy frameworks for } \\
\text { stimulating development of the national machine- } \\
\text { building industry }\end{array}$ & $x_{5}$ \\
\hline
\end{tabular}

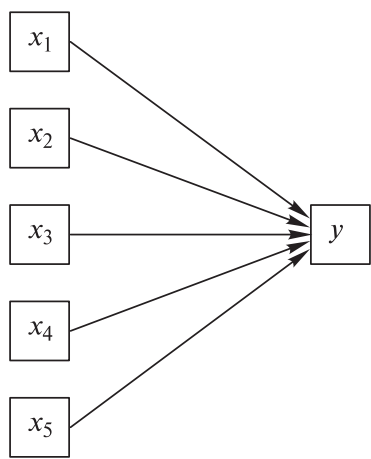

Fig. 1. Scheme of dependencies of the output parameter " $Y$ " on the input parameters " $x$ " 
precision machine-building is $55.3 \%$ (corresponding to the low and medium level of influence - terms "L" and "M") the indicator $x_{4}$. That is, to improve the monetary balance of the national economy, it is suggested to significantly increase the share of exports by increasing the share of heavy machinery, including military equipment. In general, the analysis of the legislative and regulatory framework for innovative development of enterprises in Ukraine leads to the conclusion that the legislator made real steps to form a system of legal regulation of their activity. However, some pieces of legislation remain fragmentary, declarative and overly discretionary. Therefore, on the basis of the conducted research into the legislation concerning the field, it was assessed by authors that the indicator $x_{5}$ - the regulatory and legislative basis for stimulating the development of the national machine-building industry - is in the range of medium level of influence $(30-65 \%)$. In order to improve the regulatory and legal framework, to stimulate the development of the national machine-building industry, it is proposed to include this qualitative factor in the model for evaluating the development of the machine-building.

A range of changes in the input and output parameters of the proposed model for determining the level of development of the machine-building industry in the near future is presented in Table 3.

For modeling on the basis of the fuzzy set theory a database was formed, which defines the membership functions of fuzzy sets that are usually used in fuzzy rules. A fragment of the knowledge base is presented in Table 4. After selecting and specifying limits according to formalization of the input and output parameters of the model on the basis of fuzzy sets, the database according to Table 4 was implemented in the Matlab software environment.

Table 3

The level of influence of input indicators on the determining level of development of the mechanical engineering industry in the near future

\begin{tabular}{|c|c|c|c|}
\hline Marking & Parameter name & $\begin{array}{l}\text { Range of } \\
\text { indicator } \\
\text { change, } \%\end{array}$ & $\begin{array}{c}\text { Terms } \\
\text { (level of } \\
\text { influence), } \%\end{array}$ \\
\hline$Y$ & $\begin{array}{l}\text { Level of development of } \\
\text { mechanical engineering in } \\
\text { the near future }\end{array}$ & $0-100$ & $\begin{array}{c}\mathrm{L}-0-30 \\
\mathrm{M}-30-65 \\
\mathrm{H}-65-100\end{array}$ \\
\hline$x_{1}$ & $\begin{array}{l}\text { share of expenditures on } \\
\text { scientific research studies in } \\
\text { the field of machine-building } \\
\text { of the total amount of } \\
\text { expenditures on innovations in } \\
\text { the industry - } 19-21.3 \% \text { [15] }\end{array}$ & $0-100$ & $\begin{array}{l}\mathrm{L}-0-30 \\
\mathrm{M}-30-65 \\
\mathrm{H}-65-100\end{array}$ \\
\hline$x_{2}$ & $\begin{array}{l}\text { share of innovative enterprises } \\
\text { by types of economic activity in } \\
\text { the total volume of innovative } \\
\text { industrial enterprises - } \\
18.9-22.6 \%[15]\end{array}$ & $0-100$ & $\begin{array}{l}\mathrm{L}-0-30 \\
\mathrm{M}-30-65 \\
\mathrm{H}-65-100\end{array}$ \\
\hline$x_{3}$ & $\begin{array}{l}\text { share of machinery, equipment, } \\
\text { vehicles and devices in the } \\
\text { structure of Ukrainian } \\
\text { commodity exports - } \\
8.1-36.8 \% \text { [18] }\end{array}$ & $0-100$ & $\begin{array}{l}\mathrm{L}-0-30 \\
\mathrm{M}-30-65 \\
\mathrm{H}-65-100\end{array}$ \\
\hline$x_{4}$ & $\begin{array}{l}\text { level of export of machine- } \\
\text { building products by } \\
\text { subsectors }-12-55.3 \% \text { [18] }\end{array}$ & $0-100$ & $\begin{array}{c}\mathrm{L}-0-30 \\
\mathrm{M}-30-65 \\
\mathrm{H}-65-100\end{array}$ \\
\hline$x_{5}$ & $\begin{array}{l}\text { updating the legislative and } \\
\text { policy frameworks to stimulate } \\
\text { the development of the } \\
\text { national machine-building } \\
\text { industry }\end{array}$ & $0-100$ & $\begin{array}{l}\mathrm{L}-0-30 \\
\mathrm{M}-30-65 \\
\mathrm{H}-65-100\end{array}$ \\
\hline
\end{tabular}

Table 4

Knowledge base of the model "Determinative level of development of the machine-building in the near future"

\begin{tabular}{|c|c|c|c|c|c|}
\hline$x_{1}$ & $x_{2}$ & $x_{3}$ & $x_{4}$ & $x_{5}$ & $Y$ \\
\hline L & L & L & L & M & L \\
\hline L & L & M & L & L & L \\
\hline L & L & L & H & L & L \\
\hline M & L & L & L & L & L \\
\hline L & L & L & L & L & L \\
\hline L & L & L & M & L & L \\
\hline L & M & M & M & L & M \\
\hline L & L & M & H & M & M \\
\hline H & M & M & L & M & M \\
\hline H & M & M & M & L & M \\
\hline H & H & L & L & M & M \\
\hline H & L & M & L & M & M \\
\hline M & H & H & M & L & H \\
\hline M & M & H & H & M & H \\
\hline H & H & M & H & H & H \\
\hline H & H & H & H & H & H \\
\hline
\end{tabular}

It should be noted the more rules there are in the database, the more accurate the model is.

It is the database and rules of the model we have developed to evaluate the level of development of the machine-building in the short term that will allow having practical implementation both at the level of state structures and at the level of production of the machine-building. The addition of a rule base to a specific plant or a cluster of machine-building will allow adapting the model based on fuzzy sets under a real situation. The rules and knowledge base can be adjusted. The input parameters can also be supplemented and modified depending on the dynamics of machine-building, favorable or unfavorable external and internal factors.

The input parameters according to (1) are suggested to be implemented in Matlab software in a triangular form of representation, which, to our opinion, is the most appropriate for implementation, since the parameters of the model have a clear borders and are most suitable to be presented in this form. In general, the form of presentation of the input param-

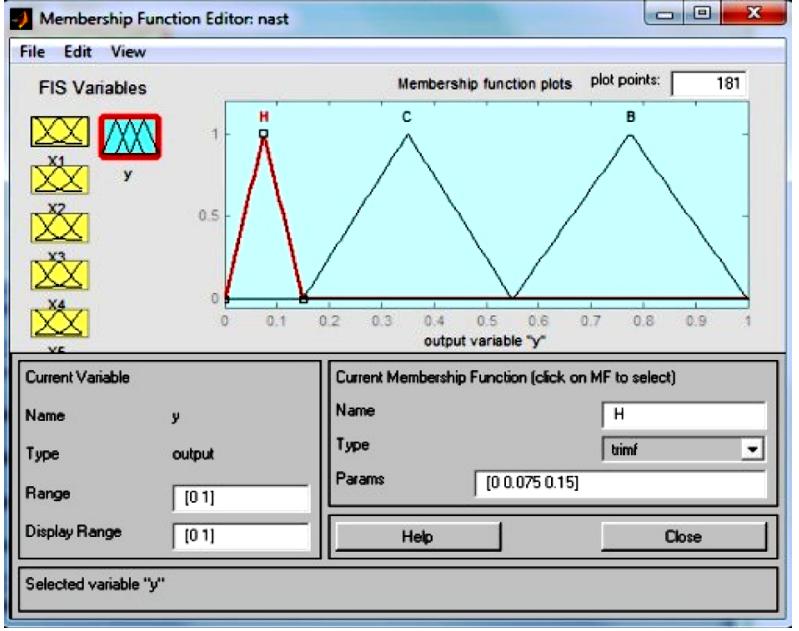

Fig. 2. Input and intermediate parameters in a triangular representation 


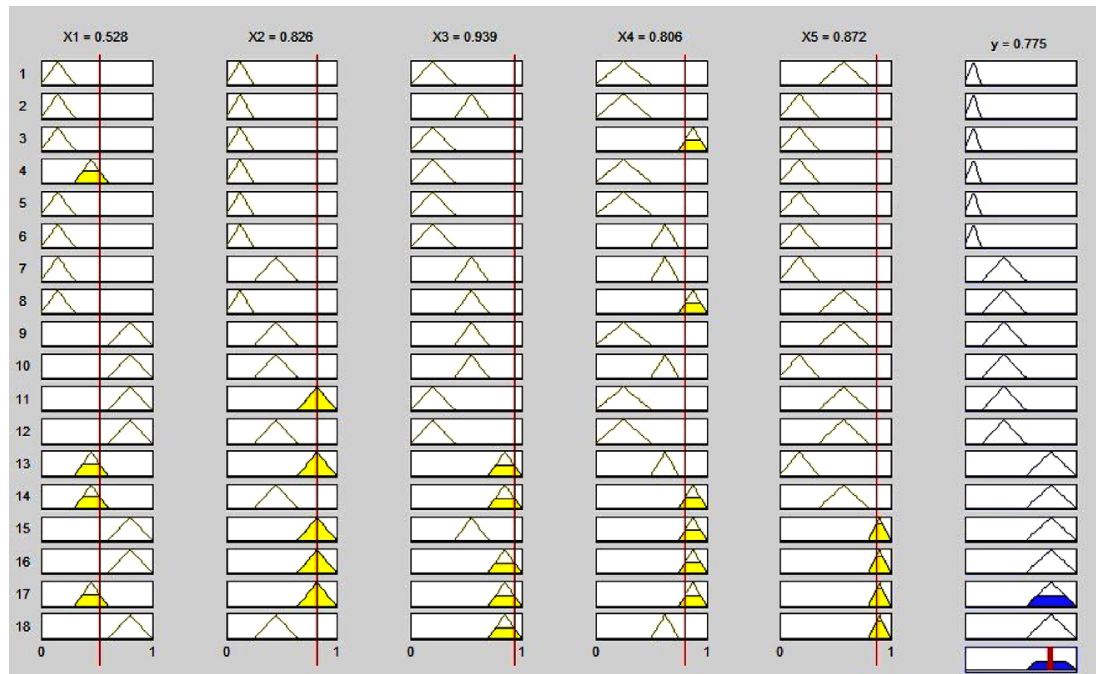

Fig. 3. Visualization of the model defuzzification for determining the level of development of the mechanical engineering industry in the near future implemented in the Matlab software environment

eters can be implemented in trapezoidal, Gaussian and other forms of presentation.

The limits of the input parameters were processed on the principle of "weights" of the Mamdani module in the Matlab software environment. This made it possible to determine at what limits: low level $(0-50 \%)$, medium level $(50-75 \%)$ or high level $(75-100 \%)$ there falls the initial indicator "Y" - the level of development of machine-building in the near future. According to the conducted simulation assuming the optimistic forecast for the development of the mechanical engineering industry, the initial indicator "Y" is $0.775(77.5 \%)$, which belongs to a high level of development.

Taking into account the factors described above, optimistic forecast for the development of machine-building is presented in Fig. 3.

Without taking into account these factors (Table 3), the prospect of the development of the national machine-building industry will be at a pessimistic forecast of $0.35(35 \%)$, which corresponds to a low level of development. That is, for the optimistic scenario implementation of the development of the machine-building enterprises, it is preferred to take into account suggested qualitative indicators.

Conclusions. The paper deals with the tendencies of development of the machine-building industry in Ukraine for the period of 2010-2017. In spite of the fact that the machinebuilding complex in the structure of investments in the fixed capital makes more than one third, it was revealed that for the period of 2010-2017 the number of enterprises, employed workers involved in the field was steadily decreasing. The main factors for stabilizing the situation in machine-building are: internal macroeconomic situation, the level of innovation management, profitability, scientific and technical potential, the degree of participation in international division of labor, trade and investment flows, focusing government efforts on the development of favorable conditions, quality and efficiency of the system, the state of infrastructure, the state and qualification of labor resources, socio-economic and internal political situation in the country.

It is also worth noting that the government's actions aimed at protecting and lobbying the interests of the domestic producer in the world market are important in stimulating the development of the machine-building complex. Development of targeted integrated innovation programs is required to implement this aim. Such programs should take into account the forecasts of industrial development, should be based on modern methods of analysis of the state of machine-building, and include the factor of scientific and technical development and innovations not only in the technical sphere, but also in the managerial one.

We have developed a model for assessing the level of development of the machine-building industry in the near future using a tool of economic and mathematical modeling based on the fuzzy set theory. According to the simulation, optimistic and pessimistic development forecasts were estimated. According to the optimistic forecast, that is, taking into account qualitative factors, the initial indicator "Y" - the level of development of mechanical engineering in the near future is 0.775 $(77.5 \%)$, which belongs to a high level of development. Excluding qualitative parameters, the prospects for the development of the national machine-building will be at a pessimistic level of $0.35(35 \%)$, which corresponds to a low level of development.

The research has shown that national mechanical engineering manufacturers are now in difficult conditions, but state support, development and implementation of innovations, as well as taking into account the qualitative factors of the proposed model for determining the level of development of enterprises in the mechanical engineering industry, will help to improve and diversify the volume of production of machine-building enterprises in the near future.

\section{References.}

1. Fedyshyn, I. B. (2011). Machine building complex: trends and ways out of the crisis. In Proceedings of the II International Scientific and Methodological Conference - Forum of Young Economists Cybernetics "Modeling in Economics: problems, trends, experience”, (pp. 97-99). Ternopil, TIPNTU. Retrieved from http:// elartu.tntu.edu.ua/bitstream/123456789/19529/1/2 zbirnyk 2011.pdf.

2. Smerichevskyi, S. F. (Ed) (2017). Research on the development of the machine-building industry of Ukraine: state and prospects. Multi-authored monograph. Riga: "Izdevnieciba "Baltija Publishing". Retrieved from https://www.researchgate.net/publication/322052953 Research on the development_of the machine-building_industry_of_Ukraine state and prospects.

3. Ravlyk, N.V. (2015). Assessment of the real state of enterprises of the machine-building industry of Ukraine on foreign and domestic markets. Ekonomika. Upravlinnia. Innovatsii, (1). Retrieved from http://nbuv.gov.ua/UJRN/eui 2015 131 .

4. Tirole, J., \& Rendall, S. (2017). Economics for the common good. Princeton, New Jersey: Princeton University Press. ISBN: 9780691175164.

5. Bahrova, I. V., \& Tyshchenko, T. I. (2012). Evaluation of the innovative potential of an industrial enterprise. Naukovyi Visnyk Natsionalnoho Hirnychoho Universytetu, (3), 139-144. 
6. Amosha, O. I. (2017). Innovative development of industrial enterprises in regions: problems and prospects. Ekonomika Ukrainy, (3), 20-34.

7. Hakhovych, N.H., \& Zavhorodnia, M.Yu. (2017). Machine-building of Ukraine: Retrospectives and Prospects. Ekonomichnyi Visnyk Universytetu, 34(1), 37-47.

8. Herasymchuk, V. H., \& Lypysiienko, A. P. (2018). Trends in development of machine building complex of Ukraine. Naukovyi Visnyk Uzhhorodskoho Natsionalnoho Universytetu. Seriia: Mizhnarodni ekonomichni vidnosyny ta svitove hospodarstvo, 19(1), 75-79.

9. Korotkyi, Yu.V. (2015). Machine building industry of Ukraine: achievements and prospects. Naukovyi Visnyk Mizhnarodnoho Humanitarnoho Universytetu. Seriia: Ekonomika i menedzhment, (11), 117-120.

10. Nazarov, D. M. (2013). Technology of decomposition on the basis of fuzzy classifier. News of Ural State Economic University, 5(49), 54-59.

11. Karelina, O. V., \& Harmatiy, N. M. (2016). Modeling economic processes by means of specialized software. In Modern socio-economic problems of the theory and practice of economic systems development: monograph, (pp. 172-192). Ternopil: FOP Osadz Y.V.

12. Amosha, O. I., Buleiev, I. P., Zemliankin, A. I., Zbarazska, L. O., \& Harazishvili, Y. M. (2017). Industry of Ukraine 2016: the state and prospects of development: analytical report. Kyiv: National Academy of Sciences of Ukraine, Institute of Industrial Economics.

13. Kryvoviaziuk, I. V., \& Strilchuk, R. M. (2016). Management of strategic capabilities of mechanical engineering enterprises: monograph. Rivne: Volynski oberehy.

14. Pohrebniak, A. Yu. (2013). Condition of mechanical engineering enterprises in post-crisis recovery. In Scientific and technical development: economics, technologies, management: International research and practice conference, (pp. 69-69), April 2-5, 2013. Natsionalnyi Tekhnichnyi Universytet Ukrainy "KPI", Kyiv. Retrieved from https://ela.kpi.ua/ handle/123456789/4275.

15. State Statistics Service of Ukraine (n.d.). Retrieved from http: //www.ukrstat.gov.ua.

16. August production went down (2018). Retrieved from http:// ukrautoprom.com.ua/uk/avgustovskoe-proizvodstvo-ushlov-minus.

17. Ukraine increases production of cars: analytical review (2018). Retrieved from https://www.rbc.ua/ukr/news/ ukraina-narashchivaet-obemy-proizvodstva-1518171031.html. 18. Kokot, V. (2018). Sectoral export strategy of the machinebuilding. engineering. analytical background. Kyiv: Ministerstvo ekonomichnoho rozvytku i torhivli Ukrainy. Retrieved from http://ref.org.ua/info/news/uchast\%60-u-robochiygrupi-z-rozrobky-ta-vprovadzhennya-strategiyi-eksportusektoru-mashynobuduvannya/?sphrase $\mathrm{id}=12$.

\section{Моделювання розвитку машинобудування на базі теорії нечітких множин}

\section{Р. М. Рогатинський, Н. М. Гарматій, І. Б. Федишин, Д. В. Дмитрів}

Тернопільский національный технічний університет імені I. Пулюя, м. Тернопіль, Україна, e-mail: rogatynskyi@ gmail.com; ira.fedyshyn@gmail.com

Мета. Оцінка стану розвитку машинобудівної галузі України в цілому та окремих іiі підгалузей на фоні сучасного макро-, мікросередовища та в контексті нової геополітичної ситуації. Для вироблення пропозицій щодо економічного співробітництва 3 іноземними інвесторами, зокрема, країнами СС у сфері машинобудування, поставлено завдання здійснити моделювання розвитку галузі на базі теорії нечітких множин.
Методика. Дослідження базується на загальнонаукових методах (аналіз, синтез, порівняння, метод формалізації та ін.) та методах статистичного аналізу даних. Дані щодо основних показників діяльності підприємств машинобудування (кількість підприємств, кількість зайнятих працівників, середньомісячна номінальна заробітна плата працівників, обсяг реалізованої продукції підприємствами машинобудування), а також обсяг прямих інвестицій з України до економік країн світу за період 2010-2017 надані Державною службою статистики України. Для дослідження та моделювання розвитку національної галузі машинобудування України на найближчу перспективу використано апарат нечіткої логіки (нечітких множин). Це є одна з найбільш ефективних математичних теорій, спрямованих на формалізацію та опрацювання невизначеності інформації.

Результати. У роботі розглянуті тенденції розвитку машинобудівної галузі в Україні за період 2010-2017 років. Незважаючи на те, що у структурі інвестицій в основний капітал машинобудівний комплекс становить більшу третину, виявлено, що за період 2010-2017 років кількість підприємств, зайнятих працівників, задіяних у сфері машинобудування, стабільно скорочується. Застосовуючи інструментарій економіко-математичного моделювання на базі нечітких множин, авторами була розроблена модель оцінювання рівня розвитку машинобудування на найближчу перспективу. Згідно із проведеним моделюванням було розроблено оптимістичний і песимістичний прогноз розвитку машинобудування України з урахуванням та без урахування запропонованих параметрів, що впливають на даний час на діяльність підприємств машинобудування в контексті нової геополітичної ситуації.

Наукова новизна. За допомогою інструментарію економіко-математичного моделювання на базі нечітких множин розроблена модель оцінювання рівня розвитку галузі машинобудування на найближчу перспективу. Наукова новизна полягає в підборі авторами чинників кількісного та якісного характеру, що мають суттєвий вплив на динаміку розвитку машинобудування України. Покращення запропонованих параметрів дозволить вивести галузь машинобудування України на європейські та світові ринки й суттєво покращити макроекономічні показники національної економіки.

Практична значимість. Розроблена авторами модель визначення рівня стану галузі машинобудування України дозволить визначати цей стан з урахуванням якісних і кількісних чинників, адаптуючи вказані параметри до реальних умов розвитку економіки України, та диверсифікувати обсяг виробництва підприємств машинобудування на найближчу перспективу.

Ключові слова: економічний розвиток, підприємства машинобудування, металургія, автомобілебудування, теорія нечітких множин

\section{Моделирование развития машиностроения на базе теории нечетких множеств}

\section{Р. М. Рогатинский, Н. М. Гарматий, И. Б. Федишин, Д. В. Дмытрив}

Тернопольский национальный технический университет имени И.Пулюя, г. Тернополь, Украина, e-mail: rogatynskyi@gmail.com; ira.fedyshyn@gmail.com

Цель. Анализ состояния развития машиностроительной отрасли Украины в целом и отдельных ее подотраслей на фоне современной макро-, микросреды и в контексте новой геополитической ситуации. Для выработки предложений по экономическому сотрудничеству с иностранными инвесторами, в частности, странами ЕС в сфере машиностроения, поставлена задача осуществить 
моделирование развития отрасли на базе теории нечетких множеств.

Методика. Исследование базируется на общенаучных методах (анализ, синтез, сравнение, метод формализации и др.) и методах статистического анализа данных. Данные по основным показателям деятельности предприятий машиностроения (количество предприятий, количество занятых работников, среднемесячная номинальная заработная плата работников, объем реализованной продукции предприятиями машиностроения), а также объем прямых инвестиций из Украины в экономики стран мира за период 2010-2017 предоставлены Государственной службой статистики Украины. Для исследования и моделирования развития национальной отрасли машиностроения Украины на ближайшую перспективу использован аппарат нечеткой логики (нечетких множеств). Это одна из наиболее эффективных математических теорий, направленных на формализацию и обработку неопределенности информации.

Результаты. В работе рассмотрены тенденции развития машиностроительной отрасли в Украине за период 2010-2017 годов. Несмотря на то, что в структуре инвестиций в основной капитал машиностроительный комплекс составляет большую треть, обнаружено, что за период 2010-2017 годов количество предприятий, занятых работников, задействованных в сфере машиностроения, стабильно сокращается. Применяя инструментарий экономико-математического моделирования на базе нечетких множеств, авторами была разработана модель оценки уровня развития машиностроения на ближайшую перспективу. В соответствии с проведенным моделиро- ванием был разработан оптимистичный и пессимистичный прогноз развития машиностроения Украины с учетом и без учета предложенных параметров, влияющих в настоящее время на деятельность предприятий машиностроения в контексте новой геополитической ситуации.

Научная новизна. С помощью инструментария экономико-математического моделирования на базе нечетких множеств, разработана модель оценки уровня развития отрасли машиностроения на ближайшую перспективу. Научная новизна заключается в подборе авторами факторов количественного и качественного характера, которые имеют сушественное влияние на динамику развития машиностроения Украины. Улучшение предложенных параметров позволит вывести отрасль машиностроения Украины на европейские и мировые рынки и существенно улучшить макроэкономические показатели национальной экономики.

Практическая значимость. Разработанная авторами модель определения уровня состояния отрасли машиностроения Украины позволит определять это состояние с учетом качественных и количественных факторов, адаптируя указанные параметры к реальным условиям развития экономики Украины, и диверсифицировать объем производства предприятий машиностроения на ближайшую перспективу.

Ключевые слова: экономическое развитие, предприятия машиностроения, металлургия, автомобилестроение, теория нечетких множеств

Recommended for publication by O. A. Sorokivska, Doctor of Economic Sciences. The manuscript was submitted 07.06.19. 